\section{Działalność feministek skupionych wokół Pauliny Kuczalskiej-Reinschmit w procesie tworzenia społeczeństwa obywa- telskiego przed Wielką Wojną}

Agata Zawiszewska

TEKSTY DRUGIE 2019, NR 3, S. 226-251

DOI: 10.18318/td.2019.3.14 | ORCID: 0000-0002-8098-5748

Społeczeństwo obywatelskie jest terenem, gdzie człowiek nowoczesny w prawomocny sposób zaspokaja swój interes własny i rozwija swą indywidualność, ucząc się wszakże równocześnie wartości działania grupowego, solidarności społecznej i uzależniania swego dobrobytu od dobrobytu innych ludzi. Wychowuje go ono do roli obywateli państwa i przygotowuje do udziatu w życiu publicznym. ${ }^{1}$

I.

Dyskusja nad ideą społeczeństwa obywatelskiego kiełkująca w pogrzebowej mowie Peryklesa z V w. p.n.e.

1 Z.A. Pełczyński Solidarity and "the Rebirth of Civil Society" in Poland 1976-1981, w: Civil Society and the State. New Europeans Perspectives, ed. by J. Keane, Verso Books, London 1988, s. 364. Cyt. za: K. Kumar Społeczeństwo obywatelskie: rozważania na temat użyteczności historycznego terminu, przeł. J. Szacki, w: Ani książę, ani kupiec: obywatel. Idea społeczeństwa obywatelskiego w myśli współczesnej, wyb. i wstęp J. Szacki, przeł. B. Szacka, J. Szacki, A. Szymanowski, E. Woydyłło, Znak, Kraków 1997, s. 300.
Materiały do artykułu zostały zebrane w ramach grantu przyznanego przez Narodowe Centrum Nauki, zrealizowanego w latach 2012-1917, DEC-2012/07/B/ $\mathrm{HS}_{2} / 00335$.

\author{
Agata \\ Zawiszewska - dr \\ hab., prof. Uniwersy- \\ tetu Szczecińskiego, \\ ostatnio opubliko- \\ wała antologie: „Wia- \\ domości Literackie \\ (1924-1939). Wybór \\ (2015) i Paulina Ku- \\ czalska-Reinschmit \\ „E pur si muove...."Pu- \\ blicystyka społeczna \\ z lat 1881-1918 (2016) \\ oraz monografię: \\ "Ster" pod redakcja \\ Pauliny Kuczalskiej- \\ -Reinschmit. Lwów \\ 1895-1897 (2017). \\ Kontakt: a.zawiszew- \\ ska@gmail.com
}


przekazanej nam przez Tukidydesa w Wojnie peloponeskiej, rozpoczęta na dobre w XVIII wieku Dwoma traktatami o rzadzie Johna Locka, pogłębiona w XIX wieku przez Georga Wilhelma Friedricha Hegla i Karola Marksa, by przycichnąć na początku kolejnego stulecia - wróciła na salony Zachodu w latach 70. XX wieku za sprawą dysydentów politycznych z Europy Środkowo-Wschodniej.To, co dysydenci pisali wówczas o społeczeństwie obywatelskim w swoich diagnozach przemian politycznych, gospodarczych i społecznych zachodzących na terytoriach znajdujących się w kręgu wpływów Związku Radzieckiego, historycy, politolodzy i socjologowie szybko przejęli do opisu zjawisk występujących w tej części kontynentu już sto lat wcześniej. Komentując najważniejsze wątki tej dyskusji, w tym spory o definicje społeczeństwa obywatelskiego i typy jego relacji z państwem, narodem, rynkiem i moralnością, Jerzy Szacki ${ }^{2}$ zwrócił uwagę na przydatność rozróżnienia przez Víctora Péreza-Díaza dwóch znaczeń pojęcia. Pierwsze to społeczeństwo obywatelskie sensu lato, czyli „zbiór społeczno-politycznych instytucji”, do których należą „państwo respektujące rządy prawa”, „system instytucji społecznych, takich jak rynki (czy spontanicznie konstytuujące się porządki) i stowarzyszenia" oraz „sfera publiczna, w której podmioty te dyskutują ze sobą i z państwem o sprawach publicznych i angażują się w publiczne działania"3. Drugie to społeczeństwo obywatelskie w znaczeniu węższym, rozumiane jako „społeczne instytucje”, do których należą „rynki i dobrowolne stowarzyszenia” oraz „sfera publiczna, pozostająca (w pełni lub w ograniczonej mierze) poza zasięgiem bezpośredniej kontroli państwa"4.

Bez względu na to, którą z historycznie zmiennych definicji społeczeństwa obywatelskiego oraz który z zakresów tego pojęcia weźmiemy pod uwagę, wszystkie podkreślają fundamentalne znaczenie dobrowolnych stowarzyszeń w jego budowaniu, traktując je jako narzędzia komunikacji między państwem i obywatelami. Najszerzej rozumiał to pojęcie Alexis de Tocqueville, autor pierwszego opisu działania społeczeństwa obywatelskiego na konkretnym przykładzie Stanów Zjednoczonych końca XIX wieku. W dziele O demokracji wAmeryce do stowarzyszeń zaliczył zarówno partie polityczne, jak i samorządy lokalne, wszelkiego rodzaju szkoły społeczne, związki zawodowe, organizacje

2 J. Szacki Wstęp. Powrót idei społeczeństwa obywatelskiego, w: Ani książę, ani kupiec..., s. 5-62.

3 V.M. Pérez-Díaz Powrót społeczeństwa obywatelskiego, w: tegoż Powrót społeczeństwa obywatelskiego w Hiszpanii, przeł. D. Lachowska, wstęp do pol. wyd. V.M. Pérez-Díaz, Znak, Kraków 1996, s. 70-71.

4 Tamże, s. 73. 
rozrywkowe, kluby hobbystów, ruchy religijne, towarzystwa naukowe i kulturalne, gazety i oficyny wydawnicze itp. ${ }^{5}$. Współczesna socjologia i politologia, szczególnie anglo-amerykańska, nie zalicza partii politycznych do ruchów obywatelskich z powodu ich związków z instytucjami państwa i dążenia do przejęcia władzy. Natomiast stowarzyszenia, czyli wszelkiego rodzaju organizacje pozarządowe nienastawione na zysk, które nie mają na celu przejęcia władzy, ale mają wpływy pozwalające wywierać nacisk na instytucje państwowe i partie polityczne, określane są obecnie mianem „trzeciego sektora”.

Większość historycznych i współczesnych rozważań na temat istoty i warunków działania społeczeństwa obywatelskiego ma charakter abstrakcyjny, oderwany od przykładów konkretnych realizacji, na co zwróciła uwagę Grażyna Szelągowska7. Historycy polskiego ruchu i dyskursu emancypacyjnego są w tej szczęśliwej sytuacji, że mają do dyspozycji cykl monografii zbiorowych, poświęconych aktywności politycznej, gospodarczej, społecznej i kulturalnej Polek w XIX i XX wieku, które powstają od lat 9o. XX wieku', oraz opracowań

5 A. de Tocqueville O demokracji w Ameryce, t. 2, przeł. B. Janicka, M. Król, Znak, Kraków 1996, S. 116-117.

6 J. Szacki Wstęp..., s. 52-57. Zob. Third Sector. Comparative Studies of Non Profit Organisations, ed. by H.K. Anheier, W. Seibel, Walter de Gruyter, Berlin-New York 1990.

7 G. Szelągowska Przedmiot pracy i problemy badawcze, w: tejże Poddany i obywatel. Stowarzyszenia społeczne w Danii w dobie transformacji ustrojowej wXIX wieku, DiG, Warszawa 2002, s. 11.

8 Zob. Kobieta i społeczeństwo na ziemiach polskich w XIX w., red. A. Żarnowska, A. Szwarc, Instytut Historyczny UW, Warszawa 1990; t. 2: Kobieta i edukacja na ziemiach polskich w XIX i XX W., red. A. Żarnowska, A. Szwarc, Instytut Historyczny UW, Warszawa 1992; t. 3: Kobieta i świat polityki, cz. 1, red. A. Żarnowska, A. Szwarc, DiG, Warszawa 1994, Cz. 2, Wydawnictwo Sejmowe, Warszawa 1996; t. 4: Kobieta i kultura. Kobiety wśród twórców kultury intelektualnej i artystycznej w dobie rozbiorów i w niepodległym państwie polskim, red. A. Żarnowska, A. Szwarc, DiG, Warszawa 1996; t. 5: Kobieta i kultura życia codziennego. WiekXIX i XX, red. A. Żarnowska, A. Szwarc, DiG, Warszawa 1997; t. 6: Kobieta i praca. WiekXIX iXX, red. A. Żarnowska, A. Szwarc, DiG, Warszawa 2000; t. 7: Kobieta i kultura czasu wolnego, red. A. Żarnowska, A. Szwarc, DiG, Warszawa 2001; t. 8: Kobieta i małżeństwo, DiG, red. A. Żarnowska, A. Szwarc, Warszawa 2004; Kobieta i rewolucja obyczajowa, red. A. Żarnowska, A. Szwarc, DiG, Warszawa 2006, t. 9: Kobieta i rewolucja obyczajowa. Społeczno-kulturowe aspekty seksualności. Wiek XIX i XX, red. A. Żarnowska, A. Szwarc, DiG, Warszawa 2006; Równe prawa i nierówne szanse. Kobiety w Polsce międzywojennej, red. A. Żarnowska, A. Szwarc, red. A. Żarnowska, A. Szwarc, DiG, Warszawa 200o; Działaczki społeczne, feministki, obywatelki... Samoorganizowanie się kobiet na ziemiach polskich do 1918 roku (na tle porównawczym), red. A. Janiak-Jasińska, K. Sierakowska, A. Szwarc, Neriton, Warszawa 2008; Działaczki społeczne, feministki, obywatelki... Samoorganizowanie się kobiet na ziemiach polskich po 1918 roku (na tle porównawczym), red. A. Janiak-Jasińska, K. Sierakowska, A. Szwarc, Neriton, Warszawa 2009. 


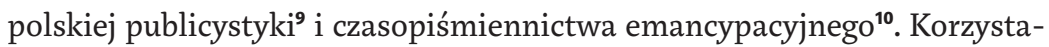
jąc z tych inspiracji, przypomnę, jaką rolę odgrywały pierwsze organizacje feministyczne na ziemiach polskich - a dokładniej: instytucje tworzone przez jedną z liderek emancypantek królewiackich, Paulinę Kuczalską-Reinschmit - w procesie kształtowania się społeczeństwa obywatelskiego przed wybuchem Wielkiej Wojny.

Aktywność feministek na przełomie XIX i XX wieku komplikuje nieco obraz relacji między społeczeństwem a państwem, które widziane są w socjologii i politologii rozmaicie, w zależności od tradycji intelektualnej i kontekstu politycznego poszczególnych badaczy. Na przykład badacze z zapleczem doświadczeń Europy Środkowo-Wschodniej ustawiają społeczeństwo w opozycji do aparatu państwa, natomiast myśliciele zakorzenieni w zachodnich demokracjach wskazują na konieczną koegzystencję państwa i społeczeństwa. Generalnie jednak większość zgadza się na dwoistą rolę państwa, które z jednej strony pełni wobec społeczeństwa funkcję gwaranta zewnętrznego i wewnętrznego bezpieczeństwa, z drugiej zaś - aparatu przymusu. W odniesieniu do polskiego ruchu emancypacyjnego sprzed 1918 roku zagadnienie to przyjmuje postać pytań badawczych sformułowanych przez Szelągowską: „czy w warunkach państwa wrogiego pod względem narodowym [...] lub niedemokratycznego możliwe jest wykształcenie się społeczeństwa obywatelskiego?"11 ,,jaką rolę w tym procesie odegrała grupa społeczna, która w tym

9 A. Górnicka-Boratyńska "Chcemy całego życia". Antologia polskich tekstów feministycznych z lat 1870-1939, Res Publica, Warszawa 1999; E. Orzeszkowa Publicystyka społeczna, t. 1, wyb. i wstęp G. Borkowska, oprac. edyt. I. Wiśniewska, Wydawnictwo Literackie, Kraków 2005; P. Kuczalska-Reinschmit „E pur si muove...". Publicystyka społeczna z lat 1881-1918, wyb. i wstęp. A. Zawiszewska, Wydawnictwo Naukowe US, Szczecin 2016; A. Siwiec Publicystyka społeczna Izabeli Moszczeńskiej, Wydawnictwo Naukowe US, Szczecin 2017; J. Szyszko-Trojanowska „Dźwigać się zawsze trzeba i walczyć ciągle". Wybór publicystyki [Cecylii Walewskiej] z lat 1897-1930, Wydawnictwo Naukowe US, Szczecin 2017.

M. Zawialska „Świt" Marii Konopnickiej. Zarys monograficzny tygodnika dla kobiet, Ossolineum, Wrocław 1978; J. Franke Polska prasa kobieca w latach 1820-1918. W kręgu ofiary i poświęcenia, Wydawnictwo SBP, Warszawa 1999; J. Franke Wokół buntu i pokory. Warszawskie czasopisma kobiece w latach 1905-1918, Wydawnictwo SBP, Warszawa 2000; A. Górnicka-Boratyńska "Ster"

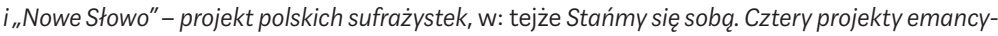
pacji (1863-1939), Sic!, Izabelin 2001.

G. Szelągowska Geneza społeczeństwa obywatelskiego a organizacje kobiece w Polsce niepodległej i czasach PRL - zarys problematyki, w: Działaczki społeczne, feministki, obywatelki... Samoorganizowanie się kobiet na ziemiach polskich po 1918 roku (na tle porównawczym), t. 2, red. A. Janiak-Jasińska, K. Sierakowska, A. Szwarc, Neriton, Warszawa 2009, s. 14. 
właśnie czasie wkroczyła w pierwszy etap emancypacji i samoorganizacji kobiety?” i która organizowała się„w warunkach stworzonych nie tylko przez państwo opresyjne i wrogie pod względem narodowym, ale także niechętne ruchom feministycznym społeczeństwo ${ }^{12}$.

Aby określić kontakty feministek ze społeczeństwem i państwem mianem oporu lub partnerstwa, trzeba uwzględnić kontekst historyczny: polityczny i ustrojowy, zmieniający się szczególnie dynamicznie w Królestwie Polskim w latach poprzedzających wybuch Wielkiej Wojny.W dużym skrócie, skupione wokół Kuczalskiej-Reinschmit środowisko emancypantek do rewolucji 1905-1907 funkcjonowało zdecydowanie jako ruch oporu wobec władzy zaborczej kontrolującej działalność publiczną, a po 1907 roku stanęło także w otwartej opozycji do tej części społeczeństwa polskiego, która sprzeciwiała się idei równych praw politycznych „bez różnicy płci”. Piszę o opozycji „otwartej”, ponieważ już przed rewolucją sprzeciw wobec konserwatywnej części społeczeństwa był przez feministki warszawskie wyrażany we własnym gronie, ale świadomie łagodzony, a nawet wyciszany w wypowiedziach publicznych. Dokumenty wytworzone przez tę grupę - spójną, aktywną przez czterdzieści lat dzięki inspiracji Kuczalskiej-Reinschmit (od ósmej dekady XIX wieku aż do odzyskania przez Polskę niepodległości), z każdą dekadą coraz bardziej widoczną nie tylko w środowisku emancypantek, ale i dla reszty społeczeństwa - oraz źródła prasowe i piśmiennictwo wspomnieniowe jej dotyczące ${ }^{13}$ pozwalają odpowiedzieć na pytania badawcze postawione także przez Żarnowską: „kiedy wśród pionierek $i$ animatorek ruchu emancypacyjnego obudziła się $\mathrm{i}$ w jakim tempie rozwijała świadomość [...] dyskryminacji? W jaki sposób narastała potrzeba aktywnego upominania się o prawa kobiet do pełnoprawnego uczestnictwa w życiu publicznym [...], a zwłaszcza prawo do zrzeszania się, traktowane jako cel sam w sobie lub środek do osiągania innych celów?"14.

12

13

14 A. Żarnowska, A. Szwarc Ruch emancypacyjny i stowarzyszenia kobiece na ziemiach polskich przed odzyskaniem niepodległości - dylematy iograniczenia. Wprowadzenie, w: Działaczki społeczne, feministki, obywatelki... Samoorganizowanie się kobiet na ziemiach polskich do 1918 roku..., s. 15. 
II.

Na terenie wszystkich trzech zaborów do początku XX wieku, a w Królestwie Polskim do rewolucji 1905-1907, państwo odgrywało dla ruchu kobiecego rolę „stymulatora negatywnego", ponieważ - nawet w najbardziej liberalnej Galicji - kobiety pozbawione były prawa wyborczego, prawa do zrzeszania się, prawa do średniego wykształcenia kończącego się maturą uprawniającą do studiów wyższych oraz prawa do edukacji uniwersyteckiej. Dostęp do edukacji średniej tożsamy z programem średnich szkół męskich kończących się egzaminem maturalnym oraz do uniwersytetów uzyskały Polki najszybciej, bo w połowie lat 90. XIX wieku, w Galicji. Cechą charakterystyczną królewiackiego ruchu kobiecego, mającą już sporą bibliotekę opracowań, była tożsamość interesów emancypacyjnych i niepodległościowych, co widać najwyraźniej w organizacji tajnego nauczania po 1863 roku. Początki polskiego społeczeństwa obywatelskiego na terenie zaboru rosyjskiego wiążą się zatem z aktywnością publiczną zwróconą przeciwko wrogiemu państwu, sprzężoną z procesem emancypacji różnych grup społecznych - samoorganizującymi się, a więc widocznymi dla samych siebie i innych części społeczeństwa ruchami masowymi, m.in. robotniczym, ludowym i kobiecym. W tym czasie kobiety nie upominały się głośno o równe prawa, ponieważ wyznawały solidarystyczne idee wypracowane w pozytywizmie, a wyrażone najpełniej w pismach Elizy Orzeszkowej, poświęcone tzw. kwestii kobiecej ${ }^{15}$. Emancypację rozumiały zatem jako dążenie do wiedzy i pracy zawodowej oraz moralne doskonalenie, by świadomie wypełniać obowiązki żony, matki i wychowawczyni kolejnych pokoleń Polaków w duchu polskości. Przeniesienie debaty intelektualnej o kondycji narodu na grunt literatury pięknej, będącej w tym czasie wehikułem idei politycznych i społecznych, w tym emancypacyjnych, spowodowało, że samo pojawienie się tzw. kwestii kobiecej w przestrzeni publicznej - jej dyskutowanie w publicystyce i beletrystyce - uważano za jej „załatwienie”. Na tę specyfikę polskiego życia intelektualnego zwracał uwagę Stefan Żeromski w swym zakopiańskim wykładzie Literatura a życie polskie wygłoszonym w 1915 roku: „Wydaje się nieraz, że skoro sprawa publicznego znaczenia poruszoną została w sposób literacki [...], to już w głębinach życia zaszło coś dodatniego, dokonała sięjakaś przemiana na lepsze. Tymczasem częstokroć na tej akcji literackiej się kończy"16.

15 G. Borkowska Publicystyka Orzeszkowej jako szkoła myślenia obywatelskiego, w: E. Orzeszkowa Publicystyka społeczna, t. 1, s. 5-36.

16 S. Żeromski Literatura a życie polskie, w: tegoż Dzieła, t. 4 Sen o szpadzie. Pomyłki, red. S. Pigoń, Czytelnik, Warszawa 1957, s. 54 . 
Początki zorganizowanego ruchu kobiecego w Królestwie Polskim przypadają na lata 8o. XIX wieku i związane są z nazwiskiem Kuczalskiej-Reinschmit (1859-1921) ${ }^{17}$. Ta wiodąca postać polskiego feminizmu pierwszej fali jako "pierwsza u nas" wystąpiła z „żądaniem pełnych, bezkompromisowych praw politycznych, społecznych, ekonomicznych i towarzyskich dla kobiety [...], pociągając za sobą Marię Szeligę, El[izę] Orzeszkową, W[alerię] Marrénową i inne"18. Jak pisała przed Wielką Wojną Cecylia Walewska w syntetycznym ujęciu Ruchu kobiecego w Polsce, Kuczalska-Reinschmit „przywiózłszy z sobą z Paryża - po wielkich międzynarodowych kongresach - szeroki dech żądzy wyzwolenia kobiet - [...] z odwagą śmiałej bojowniczki weszła ze sztandarem swoim w nasz nieuświadomiony, bierny tłum"19. Biorąc przykład z emancypantek zagranicznych, tworzyła wówczas pierwsze placówki pracy kobiecej, aż do rewolucji 1905-1907 ukrywane jednak pod szyldami różnych organizacji dobroczynnych. Zaczęła w 1886 roku od skupienia „najdzielniejszych, najsamorzutniejszych żywiołów kobiecych"20 w Komitecie Społecznym III Szwalni Warszawskiego Towarzystwa Dobroczynności. Następnie, po powrocie z kobiecych kongresów paryskich, w 1889 roku założyła tajną Unię Powszechną Kobiet, polski odpowiednik Alliance Universelle des Femmes, a rok później - legalny Komitet Damski przy warszawskim oddziale Towarzystwa Opieki nad Zwierzętami. W 1894 roku Unionistki stworzyły legalną Delegację Pracy Kobiet przy Warszawskim Towarzystwie Popierania Przemysłu i Handlu, gdzie spotykały się do 1906 roku, w 1904 roku przyjmując nową nazwę Koła Pracy Kobiet. Miejscem spotkań emancypantek skupionych wokół Kuczalskiej-Reinschmit była także Czytelnia dla kobiet prowadzona przez nią oraz jej przyjaciółkę i współpracownicę Józefę Bojanowską.

Wszystkie te placówki gromadziły i popularyzowały wiedzę o prawach regulujących pracę kobiet, działały także na rzecz poszerzania praw kobiet $\mathrm{w}$ ramach istniejącego porządku prawnego. Umieścić je zatem można w nurcie zwanym obecnie feminizmem liberalnym, co expressis verbis wyraziła w 1897 roku sama Kuczalska-Reinschmit w broszurze Nasze drogi i cele.

17 J. Hulewicz Kuczalska-Reinschmit Paulina (1859-1921), w: Polski słownik biograficzny, t. XVI, z. 1, Wrocław 1971. C. Walewska Ruch kobiecy w Polsce, cz. 1, Gebethner i Wolff, Warszawa 1909, s. 18-19. Tamże, s. 19. 
Szkic do programu działalności: „Każdy program mający służyć do usystematyzowania działalności w danym kierunku musi trzymać się podstawy, jaką wytworzyły dotychczasowe czynności i stosować się najściślej do warunków danej chwili. Bo program taki to nie wyraz życzeń i pragnień, ale przegląd czynności i starań możliwych do wykonania lub podjęcia"21. Członkinie wymienionych wyżej instytucji prowadziły wprawdzie tajne i legalne akcje oświatowe wśród przedstawicieli uboższych warstw społecznych, głównie organizując kursy dokształcające i szkoły niedzielne dla robotnic, jednak ich najważniejszą funkcją było dyskutowanie idei równouprawnienia oraz tworzenie koncepcji przekładania ich na warunki życia pod zaborami. Część środowiska emancypantek dystansowała się wobec stricte feministycznych spekulacji Kuczalskiej-Reinschmit, co wyraziła oględnie Walewska, stwierdzając, że Delegacja Pracy Kobiet tworzyła „pomysły robót społecznych, które w czyn wprowadzały najczęściej inne ręce, ale których zawsze pierwsze ziarna tam jednak zakiełkowały i wzeszły. [...] Teoretyczny umysł p. K.R. nie czuł się dobrze na gruncie czysto praktycznych robót, które służyły dla niej zawsze tylko jako placówki szerzenia idei równouprawnienia"22. Zasady organizujące prowadzoną działalność społeczną Kuczalska-Reinschmit wykładała i komentowała w swoich tekstach publicystycznych, które zamieszczała od czasu debiutu w 1881 roku na łamach pism warszawskich, m.in. „Echa”, „Świtu”, „Przeglądu Tygodniowego”, „Kuriera Warszawskiego”, „Tygodnika Mód i Powieści”, ,Ogniwa” czy „Nowej Gazety”. Podczas krótkiego pobytu we Lwowie, w latach 1895-1897, redagowała także czasopismo „Ster. Dwutygodnik dla spraw wychowania i pracy kobiet". Jak wynika z badań Jolanty Sikorskiej-Kuleszy, na XIX-wiecznym etapie swojej działalności organizacyjnej i publicystycznej Kuczalska-Reinschmit konstruowała model świadomości i pamięci historycznej emancypantek, opierający się na rozumieniu historii jako magistra vitae, czyli jako „wzoru, ostrzeżenia, zachęty”23. Oferował on zwolenniczkom równouprawnienia gotowe strategie działania sprawdzone w przeszłości, a przeciwnikom emancypacji przedstawiał

21 P. Kuczalska-Reinschmit Nasze cele i drogi. Szkic do programu działalności kobiecej, Redakcja „Steru” Lwów 1897, s. 2. wstępne o „używaniu” historii), w: Pamięć historyczna kobiet, red. M. Przeniosło, K. Sierakowska,
Wydawnictwo Uniwersytetu Humanistyczno-Przyrodniczego Jana Kochanowskiego, Kielce 2009, s. 14 . 
historyczne dowody na powszechność dążeń feministycznych i społeczne pożytki z demokratycznych nowinek.

Publicystykę Kuczalskiej-Reinschmit, podobnie zresztą jak dorobek jej współpracownic, można, a nawet trzeba czytać nie tylko jako wyraz ich osobistych poglądów na status kobiety w społeczeństwie polskim przełomu XIX i XX wieku, lecz również jako głos reprezentujący różne stowarzyszenia emancypantek. Ten ogromny korpus wystąpień prasowych i broszur, wywołujących wówczas gorące publiczne dyskusje, obecnie pozostaje w cieniu mistrzowskich dokonań beletrystów i kronikarzy epoki - wystąpień niedoczytanych z powodu swego pogranicznego charakteru: ni to krytyka literacka, ni to socjologia, ni to pedagogika. Teksty te nadal czekają na badaczy, którzy zechcieliby w nich dostrzec coś więcej niż tylko dyskurs zbanalizowanego hasła równych praw „bez różnicy płci”, a mianowicie - interesujące, zróżnicowane, niekiedy wzajemnie sprzeczne projekty wspólnot alternatywnych zarówno wobec instytucji organizujących wyobraźnię i praktyki codzienności konserwatywnego społeczeństwa, jak też narzuconych przez państwo wrogie narodowo instytucji organizujących przestrzeń publiczną.

Już w najwcześniejszych wystąpieniach prasowych Kuczalska-Reinschmit zwracała uwagę na fundamentalną rolę stowarzyszeń kobiecych zarówno w procesie emancypacji samych kobiet, jak i w procesie demokratyzacji całych społeczeństw. Powoływała się wówczas na przykłady zagraniczne znane jej z autopsji. Na przykład w latach 8o. XIX wieku, kiedy wyjechała na studia do Szwajcarii i dla nauki tkactwa warsztacikowego do Francji, publikowała na łamach „Świtu” redagowanego przez Marię Konopnicką korespondencje omawiające działalność niemieckich, francuskich i szwajcarskich organizacji. Proponowała w nich Polkom naśladowanie sprawdzonych przez nie strategii wywierania nacisku na partie polityczne i inne ośrodki władzy w celu poszerzania edukacyjnych, zawodowych, obyczajowych i politycznych praw kobiet. Na początku lat 9o. w emancypacyjnej kronice E pur si muove... prowadzonej na łamach "Przeglądu Tygodniowego" popularyzowała ideę międzynarodowych kongresów narodowych organizacji kobiecych oraz wiedzę o zagranicznych i polskich kobiecych stowarzyszeniach oświatowych i zawodowych, spółkach gospodarczych, wspólnotach mieszkaniowych itd. Doświadczenia zagranicznych koleżanek wykorzystywała we własnej pracy społecznej i intelektualnej, zakładając podobne instytucje w Warszawie, do lat 1905-1907 mające postać różnych „delegacji” czy „kół” kobiecych przy działających od dawna towarzystwach skupiających głównie mężczyzn i przez nich prowadzonych. Głęboko wierzyła i dawała temu wyraz w swojej 
publicystyce, że sprawdzona strategia emancypantek zagranicznych - jasne określenie celów i zadań, skupienie się na jednym aktualnym problemie, gotowość do podejmowania działań długofalowych, metoda małych kroków, zgoda na porażki w bitwach, by wygrywać wojny, unikanie emocjonalności i agresywnego tonu w wystąpieniach publicznych, stosowanie argumentów dowiedzionych przez naukę lub doświadczenie itd. - pozwoli osiągnąć Polkom równie dobre wyniki.

Współzałożycielki i członkinie kobiecych, zakładanych z inspiracji Kuczalskiej-Reinschmit „przybudówek” do wcześniej istniejących instytucji, konfrontowały się wówczas z przykrą rzeczywistością, w której pozytywistyczne solidarystyczne hasła głoszone przez mężczyzn zasiadających w różnych gremiach decyzyjnych nie przekładały się na prokobiece praktyki równościowe. Przykładem może być proces przekształcania sekcji rzemieślniczej tajnej Unii Powszechnej Kobiet w legalną Delegację Pracy Kobiet w 1894 roku oraz podjęta przez Delegację udana akcja przyjęcia kobiet do cechów rzemieślniczych. Po gorącej wymianie zdań podczas posiedzeń Sekcji Rzemieślniczej przy Towarzystwie Popierania Rosyjskiego Przemysłu i Handlu oraz na łamach prasy pierwsze rzemieślniczki zostały wprawdzie przyjęte do cechu krawców, ale mistrzynie nie otrzymały równych praw w wyborach na starszych cechowych ${ }^{24}$. Bolesław Prus napisał wówczas: „My wiemy, że praca zależy od trzech zmiennych: siły fizycznej, wiedzy i kapitału. Ale nie jesteśmy w stanie pojąć: jaką specjalną rolę odgrywa - płeć pracownika i z jakiej racji dla sześciu kobiet, zapisanych w cechu, mają być zmienione ustawy?"25. Dyskusja o prawach wyborczych kobiet w cechach i odmowa ich przyznania przez męski zarząd, a w kolejnych latach dyskryminowanie rzemieślniczek ubiegających się o zapomogi czy stypendia zagraniczne na podnoszenie kwalifikacji zawodowych, uświadomiły emancypantkom z kręgu Kuczalskiej-Reinschmit, że ich działalność to ruch oporu nie tylko wobec władzy państwa obcego pod względem narodowym, ale także wobec konserwatywnej części własnego społeczeństwa: „znacznej grupy mężczyzn, a i niemałej liczby kobiet przywiązanych do tradycyjnych

24 A. Zawiszewska Delegacja Pracy Kobiet, w: tejże „Ster" pod redakcją Pauliny Kuczalskiej-Reinschmit. Lwów 1895-1897 (z antologią i bibliografią zawartości), Wydawnictwo Naukowe US, Szczecin 2017, S. 161-173. 
ról społecznych i obawiających się dekonstrukcji «odwiecznych» relacji oraz hierarchii między płciami"26.

III.

Podczas dwuletniego pobytu we Lwowie, gdzie redagowała pismo „Ster", Kuczalska-Reinschmit przemyślała dotychczasowy etap swojej działalności, na którym była zafascynowana ideami zagranicznymi i przekonana o możliwości ich wdrożenia na ziemiach polskich bez konieczności uwzględniania lokalnego kontekstu politycznego, a zwłaszcza mentalnego. Zamykając „Ster” w 1897 roku, w którym kobiety w Galicji uzyskały prawo wstępu na wyższe uczelnie, „dla wyrównania prenumeraty II rocznika ${ }^{27}$ dołączyła do ostatniego numeru cytowany już szkic Nasze cele i drogi. Szkic do działalności kobiecej. Pełnił on funkcję z jednej strony podsumowania dotychczasowych osiągnięć polskich emancypantek w Królestwie Polskim i Galicji, z drugiej zaś - autorskiego planu Kuczalskiej-Reinschmit ich przyszłych działań po powrocie do Warszawy. Konieczność opracowania spójnego „programu działalności kobiecej" uzasadniała autorka ówczesną sytuacją społeczną na ziemiach polskich, na których kształtowały się nowe podziały ideologiczne. Niepokoił ją mianowicie fakt, że ani ideolodzy nowych ruchów masowych, głównie robotniczego i ludowego, ani liderzy ugrupowań konserwatywnych nie uwzględniali równouprawnienia kobiet w politycznych wizjach niepodległego państwa. Zdaniem redaktorki „Steru” wynikało to z niedostatecznego „uwidocznienia sił i wagi”28 kobiet jako odrębnej grupy interesów.

Pierwsza część szkicu Kuczalskiej-Reinschmit stanowi syntetyczne przypomnienie chlubnej tradycji „matron naszych",które jako córki, siostry i żony były przyjaciółkami swych ojców, braci i mężów; jak oni, kształciły się, pracowały i władały bronią, a pod ich nieobecność samodzielnie gospodarowały i zarządzały majątkami.Źródłem, a zarazem warunkiem mądrości, odwagi i zdrowia kobiet epoki staropolskiej oraz szacunku, jakim cieszyły się w rodzinach i sąsiedztwie, było „surowe pojmowanie życia jako ob owiązku i pracy”29. Ten sposób

\footnotetext{
26 A. Żarnowska, A. Szwarc Ruch emancypacyjny i stowarzyszenia kobiece na ziemiach polskich przed odzyskaniem niepodległości..., s. 14.

27 Od Redakcji, „Ster" $1897 \mathrm{nr} 24$ (48), s. 338.

28 P. Kuczalska-Reinschmit Nasze cele idrogi..., s. 1.

29 Tamże, s. 9.
} 
myślenia i styl życia zdezaktualizowały się w XVII i XVIII wieku pod wpływem kultur obcych, wychowania klasztornego panien i literatury romansowej, dostarczającej młodzieży fałszywych wyobrażeń o społecznej roli kobiety. Nowy model wychowania salonowego okazał się niewydolny w zderzeniu z konsekwencjami przegranego powstania styczniowego, dlatego Kuczalska-Reinschmit, idąc za propozycjami pedagogiki pozytywistycznej, postulowała zastąpienie go modelem kształcenia realnego i wychowania przygotowującego kobiety do samodzielnego życia i pracy zarobkowej. Zdaniem autorki szkicu sednem „kwestii kobiecej” jest bowiem niezależność ekonomiczna kobiet zbudowana na fundamencie rzetelnej edukacji i pracy.

W drugiej części szkicu Kuczalska-Reinschmit omówiła polską specyfikę „kwestii kobiecej”, która polega na tym, że postęp dokonuje się w niej „niemal wyłącznie dzięki inicjatywie indywidualnej, prawie bez zasadniczej walki o prawa kobiety jako człowieka, bez naukowego zgłębiania kwestii emancypacji kobiet ani badania, jakie stanowisko im wytworzyły zmienione obecnie warunki bytu"30. Ponieważ osiągnięcia zagranicznego ruchu kobiecego, znane Polkom dzięki przekładom zagranicznej proemancypacyjnej literatury pięknej i naukowej oraz miejscowym kampaniom publicystycznym i odczytowym, „nie zdołały wywołać zorganizowania tzw. ruchu kobiecego ani żywej propagandy emancypacji kobiet słowem i piórem"31, Kuczalska-Reinschmit doszła do wniosku, że na ziemiach polskich sprawa kobiet musi być inaczej „postawiona” niż na Zachodzie. Inaczej niż kobiety zachodnie, które w „akcji zbiorowej opartej na ogólnoludzkich zasadach emancypacji” walczą o prawo działania na rzecz swych narodów, Polki „zgodnie z tradycją historyczną” powinny „dążyć do rozszerzania ciągle udziału swego w pracy nad kulturą narodową - odpowiednio do ducha czasu i warunków obecnego bytu”32. Zdaniem Kuczalskiej-Reinschmit „dobro powszechne” pod koniec XIX wieku wymagało od Polek działania na „zasadach z dawnych naszych tradycji wysnutych”, a mianowicie: „powrotu do dawnej tradycji pracy kobiet we wszystkich sferach społecznych”, ,powrotu do zharmonizowania poglądów i dążności tak kobiet, jak i mężczyzn, do jednych (wspólnych) ideałów i celów jednymi drogami, aby w rodzinach rozwijać się mogło owe całkowite zrównanie, bez którego nie ma zupełnej wspólności i zupełnego szczęścia

31 Tamże.

32 Tamże, s. 13. 
w małżeństwie”, „powrotu do hartownego wychowania matek-obywatelek, które same silne fizycznie i moralnie wychowywać będą przyszłe pokolenia"33.

Tymi zasadami powinny kierować się kobiety w pracach służących unowocześnieniu edukacji żeńskiej, poszerzeniu rynku zatrudnienia kobiet i zwiększeniu ich zaangażowania obywatelskiego. Prace te, co istotne, a co rozumiało się samo przez się, miały być podejmowane dobrowolnie i wykonywane w ramach organizacji pozarządowych, a więc niemających szans na jakiekolwiek oparcie w strukturach państwa zaborczego, a nawet - co bardziej prawdopodobne - w warunkach prześladowania z jego strony.

Nowoczesne wychowanie kobiet - zdaniem Kuczalskiej-Reinschmit polega zatem na ujednoliceniu programu kształcenia dziewcząt i chłopców na wszystkich poziomach edukacji, organizowaniu zawodowego, średniego i wyższego szkolnictwa żeńskiego, zastępowaniu dominującego w kształceniu dziewcząt profilu humanistyczno-literackiego profilem realnym, uwzględniającym nauki ścisłe i przyrodnicze, wprowadzaniu do szkół żeńskich obowiązkowego wychowania fizycznego i zwiększeniu udziału kobiet w szkolnych gremiach decyzyjnych. Rozwojowi rynku pracy dla kobiet sprzyjają: poprawa warunków edukacji i pracy nauczycielek, powołanie inspektorek pracy w instytucjach zatrudniających kobiety, szczególnie w przemyśle, odchodzenie od modelu miejskiego gospodarstwa domowego z produkcyjno-konsumpcyjnego na konsumpcyjne, upowszechnianie nowinek technicznych ułatwiających pracę w gospodarstwie domowym i obniżających koszty zatrudniania służby, rozwijanie kobiecych gałęzi gospodarstwa wiejskiego, takich jak hodowla drobiu oraz przetwórstwo produktów odzwierzęcych i roślinnych. Działalność obywatelska kobiet powinna obejmować: wśród inteligencji i arystokracji - organizację szkolnictwa dla robotnic i włościanek oraz poprawę warunków ich pracy, wśród filantropek pracujących na rzecz podniesienia moralności społeczeństwa - organizację instytucji dobroczynnych zapobiegających prostytucji i handlowi kobietami, wśród posiadaczek prawa głosu w wyborach - działania zmierzające do jego poszerzania na inne przedstawicielki własnej płci, a wśród wszystkich kobiet sprzyjających emancypacji - tworzenie różnych stowarzyszeń wspierających sprawę kobiecą. Legalnym instytucjom tego rodzaju przypisywała Kuczalska-Reinschmit znaczenie szczególne, ponieważ przykłady emancypantek zagranicznych przekonały ją, że stowarzyszeniom łatwiej jest reprezentować, nagłaśniać 
interesy swych członkiń i bronić je niż jednostkom i grupom niesformalizowanym. W końcowym fragmencie Szkicu do programu działalności kobiecej napisała:

W ogóle stowarzyszenia kobiece bardzo wiele zdziałać mogą w spełnianiu zadań chwili obecnej, które usiłowałam pobieżnie naszkicować, a mianowicie:

W przystosowaniu wychowania dziewcząt do wymagań obecnych warunkówżycia pod względem praktycznym, zawodowym i fizycznym.

Organizowaniu i rozszerzaniu zawodowej pracy kobiet.

Krzewieniu w społeczeństwie przeświadczenia o potrzebie gruntownej i wyższejnauki dla kobiet, lepszej dla nich znajomości przystugujacych im praw iwarunków bytu oraz szerszego koła zainteresowań, a to dla dokładniejszego spetniania obowiazków rodzinnych i obywatelskich oraz zharmonizowania intelektualnego matżonków. Czynnej pracy nad upraszczaniem gospodarstwa, aby móc więcej czasu poświęcać pracy obywatelskiej w ogóle, a szczególnie w zakresie:

Wychowania, wykształcenia, higieny oraz interesów nauczycielstwa.

Straży etyki społecznej.

Popierania organizacji zawodowej pracy kobiet.

Oświaty ludu miejskiego i wiejskiego ze specjalnym uwzględnieniem kobiet.

Udziału w zarządzie dobroczynnościa publiczną.

Stowarzyszeniom bowiem snadniej podawać petycje, zapoznawać kobiety z ich prawami, spowodować zajęcie się odpowiednich osób zbieraniem danych w kraju i zagranicą [oryg. - przyp. red.], zapoznać z nimi potem stowarzyszonych i szerszą publiczność przez odczyty i wydawnictwa. W czym, przy rozbudzonym zainteresowaniu ogólnym tymi kwestiami, przyjdzie z pomocą prasa i wydawcy.

Przede wszystkim jednak stowarzyszenia muszą pamiętać, że u nas dlatego tyle wysiłków marnieje, iż brak nam świadomości podstaw - rozpatrzenia się w statystyce i w ogóle naukowego traktowania stanowiska kobiety. Od tego zatem należy rozpocząć, aby wywołać energiczniejszy udział kobiet w dalszej pracy nad naszą kulturą, a praca ta da nam krok po kroku rozstrzygnięcie sprawy kobiecej, gdyż ona stanowi nieodłączny składnik tej kultury i leży w tradycjach narodu. ${ }^{34}$ 
Podobnie jak pisma Orzeszkowej ${ }^{35}$, także streszczona tu broszura Kuczalskiej-Reinschmit, podsumowując XIX-wieczny etap walki Polek o równouprawnienie, konstruowała ten model pamięci historycznej emancypantek, który Sikorska-Kulesza nazwała modelem „męsko-kobiecej wspólnoty pracy, poświęcenia, walki i męczeństwa" ${ }^{36}$. Miał on przypominać (szczególnie mężczyznom, od których zależały decyzje o przyznaniu prawa głosu), że kobiety na równi z mężczyznami tworzyły historię, a dzięki swym zasługom zdobyły prawo do współtworzenia rzeczywistości współczesnej ${ }^{37}$. Materiał dowodowy stanowiły biografie wybitnych Polek, np. Anny Jabłonowskiej jako wzorca administratorki czy Narcyzy Żmichowskiej jako przykładu intelektualistki, wypowiedzi światłych mężów epoki staropolskiej, odwołania do powszechnych doświadczeń z okresu powstań oraz ich konsekwencji w postaci zsyłek, konfiskat itd.

Tę emancypacyjną politykę pamięci dobrze rozumiał Prus, ale w recenzji broszury Kuczalskiej-Reinschmit skrytykował ją jako rodzaj manipulacji historią i zabieg retoryczny. Wykład liderki emancypantek królewiackich porównał do „dzikiego parku”, w którym rosną "starodrzew historycznych wspomnień" i „młode płonki dzisiejszej sprawy kobiecej”, strzeżonego przez "okrutnego smoka... niechęci do mężczyzn" ${ }^{38}$. Uważał bowiem, że nawet jeśli można wskazać w wiekach dawnych przykłady Polek wybitnych, to bliższe prawdy jest traktowanie ich jako wyjątków wyróżniających się na tle społeczeństwa, w którym „harmonia męskich i kobiecych poglądów i dążności”39 wcale nie była powszechna. Zastrzeżenia Prusa budziło także przekonanie autorki - mimo starań jego wyciszenia, jednak w broszurze obecne - że kobiety stanowią jakieś „osobne stronnictwo kobiece, złączone poczuciem «krzywd» doznawanych od świata męskiego i zrozumieniem praw, których «zostały pozbawione»" ${ }^{40}$. Autor Lalki popart natomiast „program pani Re-

E. Orzeszkowa O sprawiedliwość, w: tejże Publicystyka społeczna, t. 1, s. 734-738; E. Orzeszkowa Do wyborców i wybrańców naszych ziem i miast, tamże, s. 741-743.

36 J. Sikorska-Kulesza Przeszłość w walce o prawa wyborcze kobiet na ziemiach polskich (Uwagi wstępne o "używaniu" historii)..., s. 12.

37 Tamże, s. 12-13.

38 B. Prus Kronika tygodniowa, "Kurier Codzienny” 1898 nr 86 (27.III). Cyt. za: B. Prus Kroniki, t. 15 , oprac. Z. Szweykowski, PIW, Warszawa 1965, s. 317.

39 Tamże, s. 318.

40 Tamże, s. 319. 
inschmitowej na teraźniejszość”, pod którym „każdy mężczyzna oburącz może się podpisać" ${ }^{\prime 1}$.

IV.

To samo państwo zaborcze w burzliwych latach 1905-1907 roku było postrzegane przez różne grupy ludności jako sprzyjające ich samoorganizacji, a w konsekwencji - sprzyjające społeczeństwu obywatelskiemu. Do najważniejszych aktów prawnych wydanych przez Mikołaja II w celu uśmierzenia niepokojów społecznych należały wówczas ukazy, które ostudziły zapały rewolucyjne: z sierpnia 1905 roku - zapowiadający zwołanie pierwszej Dumy, z października 1905 roku - obiecujący wprowadzenie swobód konstytucyjnych, i z marca 1906 roku - o wolności stowarzyszania się. Działaczki polskiego ruchu kobiecego już w październiku 1905 roku zorganizowały ogólnopolski zjazd w Krakowie, gdzie postanowiły podjąć publiczną akcję upominania się o prawa polityczne „bez różnicy płci”. Wykorzystały w tym celu jedyną dostępną im formę, praktykowaną również za granicą, a więc sformułowały oficjalny apel do stronnictw politycznych - narodowców, demokratów, ludowców, socjalistów - o uwzględnienie emancypacyjnego postulatu w partyjnych programach wyborczych. Zrobiły to zarówno aktywistki galicyjskie, jak i królewiackie. Sygnalizowały w ten sposób, że kobiety są już na tyle świadome i zorganizowane, by politycy zaczęli liczyć się z ich głosami.

Najbliższe lata uświadomiły zwolenniczkom równouprawnienia, że strategia proszenia jest nieskuteczna - postulat emancypantek nie został uwzględniony ani przez polskich posłów w austriackiej Radzie Państwa, ani w rosyjskiej Dumie. W Rosji parlament, kilkakrotnie rozwiązywany i sukcesywnie ograniczany w swych kompetencjach, przyznał ograniczone prawo wyborcze wyłącznie mężczyznom; cenzusowe prawa wyborcze mieli także Polacy do wiedeńskiej Rady Państwa i Sejmu Krajowego we Lwowie. Wprowadzone w 1907 roku powszechne prawo wyborcze do parlamentu austriackiego wyeliminowało kobiety, z wyjątkiem pewnej grupy właścicielek ziemskich; prawo wyborcze do rad miejskich w większych miastach przyznano jedynie płatniczkom najwyższych podatków, a we Lwowie i Krakowie ponadto kobietom z wyższym wykształceniem, części nauczycielek i urzędniczek. Okazało się zatem, że dla narodowców, liberałów, socjalistów równe prawa „bez różnicy płci” nie są istotnym narzędziem budowania społeczeństwa

41 Tamże. 
obywatelskiego - politycy reprezentujący interesy Polaków w strukturach państw zaborczych wyobrażali sobie nowoczesną polską demokrację bez kobiet ${ }^{42}$. Nawet ci, którzy odwoływali się do retoryki rewolucyjnej, w istocie reprezentowali ideologie zachowawcze, które Kazimierz Ślęczka podzielił roboczo na koncepcje „porządku przyrodzonego, naturalnego (biologizm, natura)",,porządku nadprzyrodzonego (zgodności z wolą Bożą)",,,nieopłacalności przemian” oraz „czasowej i strukturalnej hierarchii spraw do załatwienia”"43.

Takiego obrotu spraw spodziewała się Kuczalska-Reinschmit, której wystąpienie na zjeździe krakowskim ujawniło zmianę, jakiej na przełomie XIX i XX wieku uległy jej postawa i taktyka walki o równouprawnienie. Sądzę jednak, że liderka aktywistek królewiackich po prostu wróciła do swoich wcześniejszych poglądów z okresu formułowania Szkicu do programu działalności kobiecej, które czytelne były dla Prusa a które na pewien czas złagodziła, wierząc Orzeszkowej, że w specyficznej sytuacji narodu pod zaborami argumentacja wspólnej męsko-damskiej pracy nad demokratyzacją społeczeństwa polskiego szybciej trafi do umysłów i serc rodaków.W 1905 roku uznała, że feminizm stoi na "gruncie wspólnym" z socjalizmem, a najważniejszym punktem programu emancypacyjnego jest „poprawa losu robotnicy”. Stwierdziła, że można to osiągnąć wyłącznie dzięki „solidarności siostrzanej”, gdyż - jak dowodzi historia dawna i współczesna - kobiety w dążeniu do realizacji własnych potrzeb nie mogą liczyć na pomoc mężczyzn ${ }^{44}$. W latach 1905-1907 zatem wyklarował się nowoczesny feminizm środowiska skupionego wokół Kuczalskiej-Reinschmit a oparty na czterech przekonaniach uważanych obecnie za „feministyczne minimum”: „kobietom jako kobietom, na podstawie samej różnicy płci w stosunku do mężczyzn, dzieje się w społeczeństwie krzywda", "ten krzywdzący dla kobiet stan rzeczy można - w każdym razie obecnie już można - zmienić”, ,ten stan rzeczy należy zmienić”, ,w tym celu kobiety muszą same podjąć stosowne działania, nie podporządkowując własnych celów żadnym innym celom głoszonym przez inne ruchy i instytucje społeczne" ${ }^{\text {"45 }}$.

42 R. Blobaum „Kwestia kobieca” w Królestwie Polskim (1900-1914), przeł. M. Gawin, w: Działaczki społeczne, feministki, obywatelki..., s. 37-56.

43 K. Ślęczka Czynniki konserwujące system ról płciowych, w: tegoż Feminizm. Ideologie i koncepcje społeczne współczesnego feminizmu, „Książnica”, Katowice 1999, s. 32-40.

44 Protokół I. zjazdu kobiet polskich w Krakowie, który odbył się w dn. 20, 21, 22, 23 października 1905 r., "Nowe Słowo" 1905 nr 20, s. 4-5.

K. Ślęczka Wstęp, w: tegoż Feminizm..., s. 12. 
Ten nowoczesny feminizm znalazł swój instytucjonalny wyraz w 1906 roku, gdy członkinie Delegacji Pracy Kobiet przy Towarzystwie Popierania Rosyjskiego Przemysłu i Handlu (przemianowanej w 1904 roku na Koło Pracy Kobiet), powołały pierwszy Związek Równouprawnienia Kobiet Polskich pod przewodnictwem Kuczalskiej-Reinschmit. „Bluszcz” powitał nową inicjatywę obszernym materiałem informującym o programie Związku, który na pierwszym miejscu wymieniał równouprawnienie kobiet w dostępie do praw politycznych i obywatelskich, a w kolejnych punktach - korzystne dla kobiet zmiany w prawie małżeńskim, rodzinnym i majątkowym, dostęp kobiet do edukacji wszystkich szczebli i rynku pracy, ochronę pracy kobiet, walkę z podwójną moralnością, reglamentacją prostytucji i alkoholizmem:

Związek ma na celu zdobycie równouprawnienia kobiet polskich oraz ogólnych swobód obywatelskich i praw politycznych.

Związek uznaje, iż równouprawnienie kobiet stanowi nieodłączną część ogólnych dążeń wolnościowych i dlatego, jako zasadnicze hasło polityczne, stawia współdziałanie z ogólnym ruchem wolnościowym. [...]

Aby osiągnąć cele zakreślone, związek zamierza: idee swoje szerzyć przez odczyty, narady, wiece, zjazdy, wydawnictwa, ankiety, biblioteki, biura informacyjne itp.; występować do instytucji społecznych i państwowych w sprawie równouprawnienia kobiet i wprowadzenia reform w warunkach pracy kobiet; zakładać szkoły, kursy, stowarzyszenia, instytucje potrzebne do urzeczywistnienia postulatów Związku.

Związek uznaje za potrzebne łączenie się z innymi stowarzyszeniami o pokrewnych zasadach i celach. ${ }^{46}$

Ten pierwszy Związek, który powstał na wzór Związku kobiet rosyjskich, nie został jednak zalegalizowany w 1906 roku z powodu wprowadzenia stanu wojennego, a rok później rozpadł się na dwie organizacje o tożsamych niemal statutach: Polskie Stowarzyszenie Równouprawnienia Kobiet oraz Związek Równouprawnienia Kobiet Polskich z Kuczalską-Reinschmit jako prowodyrką secesji. Jedyną akcją publiczną pierwszego Związku, która odbiła się echem w prasie stołecznej, był protest przeciwko Adresowi kobiet z Królestwa Polskiego opracowanemu przez Związek Umysłowo Pracujących Polek „w łączności z pokrewnymi z nim ideowo zrzeszeniami kobiecymi

46 Z.S. [Z. Seidlerowa] Kronika działalności kobiecej, „Bluszcz” 1906 nr 1, s. 10-11. 
i poszczególnymi osobami", opublikowanemu w czerwcu 1906 roku na łamach „Bluszczu” i przedrukowanemu w „Kurierze Warszawskim” ${ }^{47}$. Adres skierowany był do liczącego 34 posłów Koła Polskiego, reprezentującego interesy Polaków w Dumie, „z prośbą o poparcie słusznych żądań kobiety polskiej” - „powszechnego prawa wyborczego bez różnicy płci”"48. Autorki adresu, określające się zbiorowo jako „my Polki”, argumentowały, że prawo wyborcze należy się kobietom jako „uczestniczkom wszystkich cierpień narodu" $i$,towarzyszkom Waszym [mężczyzn - przyp. A.Z.] w walkach o wolność i byt ojczyzny, dzielącym z Wami [mężczyznami - przyp. A.Z.] ucisk i niebezpieczeństwa” - należy się kobietom jako sprawiedliwy „udział w pracach i obowiązkach powszechnych"49.

Związek Równouprawnienia Kobiet odciął się publicznie od tej inicjatywy, wysyłając do „Kuriera Warszawskiego” Protest stwierdzający, że „uogólnienie adresu jednego Związku Umysłowo Pracujących Polek do kobiet całego Królestwa Polskiego jest błędem rażącym i uzurpacją", ponieważ „ani Związek Równouprawnienia Kobiet, ani Koło Pracy Kobiet, ani wiele innych organizacji z adresem tym nie miały nic wspólnego". Członkinie Związku Równouprawnienia "nie solidaryzują się [...] z tym wystąpieniem, bo uznają, że kobiety dla swej płci nie mogą i nie powinny wypraszać, ale zdobywać muszą na równi z prawem przedstawicielstwa powszechnego w ciałach ustawodawczych" - „zdobywać nie przez korne adresy i zapewnienia zaufania do posłów, lecz przez usilne przepracowywanie opinii publicznej i rozbudzanie w kobietach wszystkich warstw społecznych żywiołowego poczucia swoich praw, a w mężczyznach obowiązku usunięcia ciężkiej krzywdy bezprawia kobiet"50. W tym duchu członkinie Związku skierowały do „Obywatelek i Obywateli” odezwę, w której domagały się „powszechnego, równego prawa wyborczego, przy bezpośrednim tajnym głosowaniu, bez różnicy wyznania, narodowości i płci” - „w imię sprawiedliwości praw człowieka”, ,jako niezbędnego środka dla swobodnego rozwoju [...] indywidualności, zdobycia równoprawnego stanowiska

47 Zwiq̨zek Umysłowo Pracujących Polek, Adres kobiet z Królestwa Polskiego, "Kurier Warszawski” 1906 nr 174, s. 2.

48 Zwiq̨zek Umysłowo Pracujq̨cych Polek, Adres kobiet z Królestwa Polskiego, "Bluszcz” 1906 nr 25, S. 293.

49 Tamże.

50 Głosy publiczne, "Kurier Warszawski” 1906 nr 174, s. 6. 
w rodzinie i społeczeństwie, a więc i prawidłowego życia ludzkości, złożonej zarówno z kobiet, jak i mężczyzn"51.

Zdaniem redakcji „Kuriera Warszawskiego”, który opublikował oba dokumenty, apel Związku Umysłowo Pracujących Polek i protest Związku Polskiego Równouprawnienia Kobiet cechowała ta sama megalomania - obie instytucje uzurpowały sobie prawo do przemawiania w imieniu wszystkich Polek, obie też domagały się równouprawnienia politycznego kobiet. Różnica tkwiła - zdaniem redakcji gazety - w ideologii: pierwszej instytucji bliżej było do konserwatywnej Narodowej Demokracji, drugiej do liberalnej Postępowej Demokracji.

\section{V.}

Rozczarowanie emancypantek skupionych wokół Kuczalskiej-Reinschmit postępowaniem przedstawicieli męskich w praktyce partii politycznych, reprezentujących polskie interesy $\mathrm{w}$ parlamentach rosyjskim i austriackim, znalazło wyraz w reaktywowanym w Warszawie periodyku „Ster”. Wydawany w latach 1907-1914 pod redakcją Kuczalskiej-Reinschmit i Bojanowskiej „organ równouprawnienia kobiet” był zarazem platformą informacyjną ponadzaborowego środowiska walczącego o równe prawa „bez różnicy płci” oraz tubą warszawskich feministek zorganizowanych w Związku Równouprawnienia Kobiet Polskich. Hasło przewodnie środowiska i jego prasowego organu brzmiało: „powszechne głosowanie jest dopiero wówczas, gdy i kobiety głosują", a przekładało się zarówno na strukturę i treść periodyku, jak i na rodzaj aktywności społecznej podejmowanej przez emancypantki. W każdym numerze „Steru” ważną rolę odgrywały: artykuł o charakterze programowym, kronika działalności kobiecej za granicą, dyskusja czytelniczek-korespondentek, informator polskich stowarzyszeń kobiecych na terenie trzech zaborów oraz dział poświęcony Związkowi Równouprawnienia - jego zebraniom, walnym zjazdom, oddziałom pozawarszawskim, wydawnictwom, spotkaniom autorskim, odczytom promocyjnym itd.

Ideą przyświecającą Kuczalskiej-Reinschmit było nadal - podobnie jak na etapie XIX-wiecznym jej aktywności instytucjonalnej i publicystycznej - oswajanie społeczeństwa polskiego z myślą o zmianach, jakie mogłyby wprowadzić równouprawnione kobiety, oraz naciskanie na grupy szeroko pojętej „władzy”. Oswajaniu społeczeństwa służyć miała rzetelna, spokojna, 
długofalowa akcja informacyjna - na łamach prasy, podczas publicznych wieców i kameralnych odczytów, za pośrednictwem kalendarzy tematycznych, broszur, ulotek itd.; wywieranie nacisku odbywało się na drodze regularnego i konsekwentnego zabierania głosu w przestrzeni publicznej w imieniu kobiet jako zrzeszonej grupy interesów - komentowanie debat politycznych, krytykowanie konkretnych decyzji administracyjnych, wywoływanie po nazwisku do odpowiedzi na palące pytania socjalne, nagłaśnianie korzystnych dla kobiet rozwiązań wprowadzonych za granicą. Tych ostatnich na początku XX wieku przybywało, także w najbliższym - geograficznie i politycznie otoczeniu. W wypowiedziach Kuczalskiej-Reinschmit i jej współpracowników powtarzały się nie tylko takie fakty, jak najwcześniejsze akty nadania kobietom praw wyborczych: w stanie Wyoming w Stanach Zjednoczonych w 1869 roku, w 1881 roku - na wyspie Man należącej do Imperium Brytyjskiego, w 1893 roku - czynne prawo wyborcze w Nowej Zelandii, również należącej do Zjednoczonego Królestwa. Podkreślane były przede wszystkim demokratyczne rozwiązania wprowadzane przez narody od początku XX wieku wyzwalające spod niechcianej kurateli politycznej, np. w 1902 roku, a więc rok po oddzieleniu się od Wielkiej Brytanii, Australia jako pierwsze suwerenne państwo nowożytne wprowadziło prawa wyborcze dla kobiet. Dla emancypantek królewiackich najważniejszy jednak był fakt, że w 1906 roku w zależnej od Rosji Finlandii pierwszy raz zwołany parlament Eduskunta wprowadził powszechne prawo wyborcze „bez różnicy płci”. Oczywiście, ówczesna sytuacja zewnętrzna i wewnętrzna Finlandii była inna niż sytuacja Polski, zarazem jednak - jak to widziały feministki - podobna. W momencie rewolucyjnego poluzowania przez Rosję gorsetu politycznego na terytoriach od niej zależnych Finowie wkład kobiet w historię narodową uwzględnili i uznali, posłowie z Koła Polskiego w Dumie - nie.

Z powyższych względów publicystyka „Steru” warszawskiego, a zwłaszcza otwierająca pierwsze numery monografia Wyborcze prawa kobiet Kuczalskiej-Reinschmit, wydana w $1911 \mathrm{w}$ formie broszury ${ }^{52}$, należy do najwęższego modelu pamięci historycznej emancypantek, który Sikorska-Kulesza nazywa modelem „walki o prawa wyborcze «bez różnicy płci»" ${ }^{3}$. W jego ramach

52 P. Kuczalska-Reinschmit Wyborcze prawa kobiet, "Ster” 1907 nr 1/2, s. 1-31. Wyd. broszurowe: P. Kuczalska-Reinschmit Wyborcze prawa kobiet, Skład Główny Administracji „Steru”, Warszawa 1911.

53 J. Sikorska-Kulesza Przeszłość w walce o prawa wyborcze kobiet na ziemiach polskich (Uwagi wstępne o "„używaniu" historii)..., s. 13. 
krótka tradycja polskich organizacji emancypacyjnych, których członkinie spotykały się często z drwiną czy szyderstwem, wpisuje się w szerszą panoramę walk kobiet całego zachodniego świata o pełnię swych praw, postrzeganych jako część szerszej walki o prawa człowieka. Wspólna historia klęsk i sukcesów oraz legendy biograficzne męczenniczek i bohaterek tworzą feministyczną tożsamość, są źródłem indywidualnej i zbiorowej siły i odwagi emancypantek, a zwłaszcza zagrzewają je do dalszych wysiłków, ponieważ walka o równouprawnienie jeszcze się nie zakończyła. W polskiej tradycji walk o równouprawnienie publicyści „Steru” podkreślali status kobiet jako ofiar męskiej części społeczeństwa, z premedytacją wykorzystywanych jako „dromaderki i kwestarki"54 i świadomie zdradzanych w walce o rzekomo wspólne wartości narodowe. Kobiece poczucie krzywdy wzmogło się w latach 1905-1907, gdy kobieta - dotąd kreowana przez ideologów ruchów masowych na partnerkę mężczyzny, a w dziedzinie tajnego nauczania uważana niemal za niezastąpioną - okazała się rzekomo jeszcze niegotowa czy niedojrzała do przyznania jej pełni praw obywatelskich ${ }^{55}$. Pamięć polskich feministek pierwszej fali pełniła zatem rolę podwójną: z jednej strony narzucała innym określoną historię kobiet jako historię doznawanych przez nie niesprawiedliwości i ich uzasadnionych dążeń do pełni praw, z drugiej zaś była „pamięcią insurekcyjną, nieoficjalną, nielegalną, konkurencyjną wobec reprezentowanej nie tylko przez instytucje pamięci państwa (szkoła, nauka), ale niemal całe społeczeństwo (męskie media, męska nauka)"56.

W latach poprzedzających wybuch Wielkiej Wojny środowisko emancypacyjne ponownie zróżnicowało się wewnętrznie. Krąg „Steru” i Związku Równouprawnienia Kobiet Polskich odrzucał propozycje współpracy ze stronnictwami politycznymi, wyjątek czyniąc niekiedy dla socjalistów. Kuczalska-Reinschmit miała już wówczas skrystalizowane poglądy na konieczność stowarzyszania się obywateli w instytucjach niezależnych od partii politycznych, aby za ich pośrednictwem wpływać na kształt rzeczywistości. Znacznie liczniejsza grupa działaczek z Izabelą Moszczeńską-Rzepecką na czele dążyła do połączenia postulatów feministycznych z dążeniami niepodległościowymi w ramach powołanej w 1913 roku konspiracyjnej Ligi Kobiet

54 C. Walewska Dromaderki i kwestarki , "Ster" 1907 nr 1, s. 58-62.

M. Dulębianka Polityczne stanowisko kobiety. Referat wypowiedziany na Zjeździe kobiet polskich wWarszawie, "Ster" 1907 nr 7, s. 255-265; nr 8, s. 309-317.

56 J. Sikorska-Kulesza Przeszłość w walce o prawa wyborcze kobiet na ziemiach polskich (Uwagi wstępne o "używaniu" historii)..., s. 16. 
Pogotowia Wojennego ${ }^{57}$, która odwoływała się do tradycji uczestnictwa kobiet w polskich ruchach niepodległościowych i rewolucyjnych. Zgodność ideologiczna członkiń Ligi nie była priorytetem, ale Moszczeńska wyciagnęła wnioski z dotychczasowych kontaktów z politykami. Liga deklarowała bezpartyjność i współpracę ponadideologiczną ze wszystkimi organizacjami działającymi na rzecz niepodległości Polski, ale zastrzegała sobie niezależność. W ten sposób kwestia kobieca została ponownie włączona do kwestii narodowej, a walka o niepodległość stała się wspólną walką całego społeczeństwa bez różnicy płci. W połowie wojny Liga - królewiacka i galicyjska - stała się największą organizacją kobiecą na ziemiach polskich, a ich liderki miały świadomość znaczenia politycznego organizacji, dlatego coraz częściej zabierały głos na temat działań mężczyzn polityków. Akt 5 listopada 1916 roku został przyjęty przez Ligę z uznaniem i stanowił impuls do wprowadzenia do programu postulatu walki o prawa wyborcze dla kobiet. Stało się to w pierwszej połowie 1917 roku w odpowiedzi na działania warszawskiej Tymczasowej Rady Stanu, która projektując nowe państwo polskie, brała pod uwagę jedynie mężczyzn. Prawo wyborcze wyłącznie dla mężczyzn przewidywały również pierwsze projekty lewicy piłsudczykowskiej. Przewodniczącą Ligi została wówczas Zofia Moraczewska, żona Jędrzeja Moraczewskiego, ministra w rządzie Ignacego Daszyńskiego, a potem premiera pierwszego rządu powołanego przez Józefa Piłsudskiego.

Piłsudski został postawiony przed faktem dokonanym: zanim wrócił 10 listopada 1918 roku z Magdeburga, 7 listopada Ignacy Daszyński jako premier rządu lubelskiego ogłosił alternatywną wobec konserwatywnych projektów ustroju niepodległej Polski Odezwę Tymczasowego Rządu Ludowego Republiki Polskiej. Artykuł 4. odezwy zapowiadał zwołanie w tym samym roku konstytuanty „na podstawie powszechnego bez różnicy płci, równego, bezpośredniego, tajnego i proporcjonalnego głosowania. [...] Czynne i bierne prawo wyborcze będzie przysługiwało każdemu obywatelowi i obywatelce, mającym 21 lat skończonych". Równouprawnienie kobiet, podobnie jak ośmiogodzinny dzień pracy, ubezpieczenia społeczne oraz powszechna i świecka edukacja należały do pakietu reform lewicowych, budzących otwartą niechęć ugrupowań konserwatywnych i Kościoła katolickiego ${ }^{58}$. Daszyński wspominał, że

57 J. Dufrat Kobiety w kręgu lewicy niepodległościowej. Od Ligi Kobiet Pogotowia Wojennego do Ochotniczej Ligi Kobiet (1908-1918/1919), Wydawnictwo Adam Marszałek, Toruń 2002.

58 W. Najdus O rzq̨d ogólnopolski, w: tejże Ignacy Daszyński. 1866-1936, Czytelnik, Warszawa 1988, S. 391. 
z tego powodu „program demokracji polskiej”59 irytował Piłsudskiego, który obawiał się, że „skrajnie demokratyczne żądania polityczne"60 utrudnią mu negocjacje w przedstawicielami innych partii politycznych. Uważał ponadto, że Daszyński po prostu przesadza: „Gniewem ludu mi grozi i barykadami”61. Artykuł 1 Dekretu Tymczasowego Naczelnika Państwa Józefa Piłsudskiego o ordynacji wyborczej do Sejmu Ustawodawczego z 28 listopada 1918 roku powtórzył jednak za Manifestem Rządu Lubelskiego, że „Wyborcą do Sejmu jest każdy obywatel Państwa bez różnicy płci". Znaczenie Manifestu z 7 listopada dla późniejszych działań programotwórczych podsumował Moraczewski już rok później, pisząc: „Manifest stanowi kamień węgielny w budowie nowoczesnego państwa polskiego. [...] był czynem przenoszącym Polskę z końca XVIII wieku w wiek XX"62.

Przyznanie praw obywatelskich kobietom już na pierwszym etapie odbudowy państwa i scalania społeczeństwa polskiego spowodowało, że nie tylko politycy, ale także kobiety, uważały kwestię kobiecą za rozwiązaną. W niepodległej Polsce Moraczewska starała się założyć kobiecą partię polityczną, co się nie udało m.in. z powodu masowego głosowania kobiet na ugrupowania konserwatywne w pierwszych demokratycznych wyborach, a wskutek tego - wygaśnięcia zainteresowania czynną polityką wśród dużej części dawniej aktywnych działaczek Ligi Kobiet Pogotowia Wojennego. Idea emancypacji nie wyemancypowała się zatem w świadomości legionistek od kwestii narodowej na tyle, by po odzyskaniu przez Polskę niepodległości prowadzić niezależny - stricte polityczny czy stowarzyszeniowy - żywot. Wiele działaczek Ligi, zwolenniczek programu piłsudczyków, skupiło się w Związku Pracy Obywatelskiej Kobiet ${ }^{63}$; wiele z nich działało w kobiecych, ale niefeministycznych organizacjach pozarządowych. Pamięć o długiej i wyboistej drodze kobiet do równych praw „bez różnicy płci” szybko popadała w zapomnienie, czemu starała się zapobiec Walewska, która już pod koniec

59 I. Daszyński Wspomnienia, t. 2, wstęp i oprac. K. Piskała, Muzeum Historii Polski, Warszawa 2017 , s. 407.

60 Tamże.

61 B. Miedziński Wspomnienia (Dokończenie), "Zeszyty Historyczne” 1976 z. 37, s. 149.

62 [J. Moraczewski] Przewrót w Polsce, cz. 1 Rzq̨dy ludowe. Szkic wypadków z czasów wyzwolenia Polski do 16 stycznia 1919 roku, napisał poseł E.K., Redakcja tygodnika „Prawo Ludu”, KrakówWarszawa 1919, s. 23.

63 J. Dufrat W służbie obozu marszałka Józefa Piłsudskiego. Zwiq̨zek Pracy Obywatelskiej Kobiet (1928-1939), Wydawnictwo Avalon T. Janowski, Kraków 2013. 
lat 20. zainicjowała na łamach „Kobiety Współczesnej” cykl wspomnieniowy poświęcony przedwojennym emancypantkom, w formie książkowej noszący tytuł Nasze bojownice ${ }^{64}$. Jak pisze Dobrochna Kałwa, świadomość, że istnieje odrębny „świat kobiecy” zamknięty w ramach biologii, prawa i społecznych przekonań o „naturze" płci, nie była powszechna nawet wśród członkiń licznych polskich organizacji kobiecych, które wymieniały zainteresowanie problemami kobiet jako jeden $\mathrm{z}$ wielu celów statutowych, np. walki z bezrobociem, alkoholizmem czy prostytucją, nie zaś jako cel podstawowy ${ }^{65}$. Także stowarzyszenia zainteresowane równouprawnieniem skupiały się nie tyle na analizie powojennej sytuacji politycznej, ekonomicznej i prawnej kobiet, co na skłanianiu ich do korzystania ze zdobytych uprawnień - podejmowania studiów wyższych i pracy w nowych zawodach oraz angażowania się w życie polityczne na wszystkich szczeblach, aby udowodnić w ten sposób, że przyznanie im praw obywatelskich było uzasadnione ${ }^{66}$. Śmierć Kuczalskiej-Reinschmit w 1921 roku, w którym uchwalona została tzw. konstytucja marcowa potwierdzająca równość praw „bez różnicy płci”, stanowiła symboliczne zakończenie pierwszej fali polskiego ruchu emancypacyjnego jako jednego z etapów procesu budowania nowoczesnego społeczeństwa obywatelskiego.

64 C. Walewska W walce o równe prawa. Nasze bojownice, „Kobieta Współczesna”, Warszawa 1930.

65 D. Kałwa Kobieta w Polsce międzywojennej, w: tejże Kobieta aktywna w Polsce międzywojennej. Dylematy środowisk kobiecych , Historia lagellonica”, Kraków 2002, s. 28.

66 K. Sierakowska Samoorganizowanie się kobiet w II Rzeczypospolitej: dq̨żenia, szanse i realizacje, w: Działaczki społeczne, feministki, obywatelki. Samoorganizowanie się kobiet na ziemiach polskich po 1918 roku (na tle porównawczym), t. 2, red. A. Jasińska-Janiak, K. Sierakowska, A. Szwarc, Neriton, Warszawa 2009, s. 33-47. 


\section{Abstract}

\section{Agata Zawiszewska}

UNIVERSITY OF SZCZECIN

The Work of the Feminists around Paulina Kuczalska-Reinschmit in the Process of Creating a Civil Society before the Great War

In the Kingdom of Poland, Paulina Kuczalska-Reinschmit (1859-1921) and other feminists founded various women's associations with an emancipatory agenda. From the $1880 \mathrm{~s}$ until the outbreak of World War I they were facing double adversity: a state that was hostile on account of their national background and a society that resisted their claim to general enfranchisement regardless of sex. The Russian Revolution was a turning point in the history of women's associations and emancipatory discourse, for women now demanded equal civil rights. Until 1905, men and women were usually presented as engaged in a common struggle for equal rights. However, when Polish politicians refused to satisfy the feminists' demands, women began to see themselves as fighting on their own. Zawiszewska's methodology is inspired by Polish scholarship on women's social history and emancipatory discourses, which highlights the role of associations in constructing a modern civil society.

\section{Keywords}

Paulina Kuczalska-Reinschmit, Ster periodical (Lviv 1895-97, Warsaw 1907-14), Polish women's emancipation 